\title{
Penguatan Mutu Madrasah Swasta Menuju Madrasah Unggul
}

\author{
Abd Wahib \\ Fakultas Ilmu Tarbiyah Institut Pesantren KH Abdul Chalim Pacet Mojokerto \\ Email : abdulwahib@ikhac.ac.id
}

\begin{abstract}
Efforts to strengthen madrasa quality continue to be intensified, various madrasa problems must be found solutions or solutions. Madrasah management must be carried out professionally, and madrasah leadership must be optimized, and be able to revive entrepreneurs in madrasas. The aim of strengthening madrasah quality must be continued, namely to make high-achieving madrasas, with indicators of academic and nonacademic achievements above the means and infrastructure and services are more complete, the learning system is better, admission selection is quite strict, gets a lot of interest from the community and there is sufficient funds available. The research method used is a qualitative research method, which is a research method used to examine the condition of natural objects (natural settings). The results of the study show that the strengthening

of madrasa quality is done with professional management, optimizing the leadership of the madrasa

principals, and fostering entrepreneurship in the madrasa. The conclusions of this study include the management of madrasas with a professional management system, the leadership of the madrasa principals and madrasa entrepreneurs.Abstrak

Upaya penguatan mutu madrasah terus diintensifkan, berbagai masalah madrasah harus dicarikan solusinya atau penyelesaiannya. Manajemen madrasah harus dilaksanakan secara professional, dan kepemimpinan kepala madrasah harus dioptimalkan, serta mampu menghidupkan wirausaha di madrasah tujuan penguatan mutu madrasah barus terus diupayakan, yaitu menjadikan madrasah yang berprestasi dan unggul, dengan indikator prestasi akademik dan non akademik di atas rata-rata, sarana dan prasarana dan layanan lebih lengkap, sistem pembelajaran lebih baik, seleksi penerimaan cukup ketat, mendapat animo yang besar dari masyarakat dan tersedia dana yang cukup. Metode penelitian yang digunakan adalab metode penelitian kualitatif, yaitu metode penelitian yang digunakan untuk meneliti pada kondisi objek yang alamiah (natural setting). Hasil penelitian menunjukkan bahwa penguatan mutu madrasah dilakukan dengan manajemen professional, mengoptimalkan kepemimpinan kepala madrasah, dan menumbubkan wirausaha di madrasah. Kesimpulan penelitian ini meliputi pengelolaan madrasah dengan sistem manajemen professional, kepemimpinan kepala madrasah dan wirausaha madrasah.
\end{abstract}

Keywords : Penguatan Mutu, Madrasah Unggul

Nidhomul Haq: Jurnal Manajemen Pendidikan Islam

ISSN: 2503-1481 Hal: 57-63 


\section{A. PENDAHULUAN}

Keberadaan madrasah telah lama tumbuh di bumi Indonesia, diperkirakan sejak awal abad ke 20. Lahirnya madrasah di Indonesia sangat dipengaruhi oleh munculnya ide-ide pembahasan pemikiran dalam Islam. Madrasah tumbuh dan berkembang dari perpaduan antara pendidikan pesantren dan sekolah. Beberapa ciri kepesantrenan diadopsi oleh madrasah adalah ilmu agama serta sikap hidup beragama. Ciri-ciri sekolah yang oleh madrasah adalah sistem klasikal, mata pelajaran umum dan manajemen pendidikan. Pada masa penjajahan Belanda, madrasah tumbuh dan berkembang secara sparatis, tanpa dikoordinasi oleh pemerintah, dengan demikian muncullah madrasah yang beraneka ragam bentuknya.

Setelah Indonesia merdeka, pengelolaan madrasah dipercayakan kepada pemerintah, yaitu kementerian agama. Sejak Indonesia merdeka telah terjadi tiga fase perkembangan madrasah. Fase pertama, fase antara tahun 1945-1974. Pada fase ini madrasah lebih berkosentrasi kepada pengajar dan ilmu agama. Artinya kesulitan untuk mendapatkan guru yang mau dan mampu untuk mengajar dengan baik, serta berkaitan dengan ilmu agama, yaitu tauhid, fikih, tasawuf, akhlak, tafsir, hadits, AlQur'an, Bahasa Arab, sejarah Islam, dan ilmu falak. Karena itu ijazah madrasah lebih berkonsentrasi berlakunya dikalangan kementerian agama, baik bentuk melanjutkan studi maupun untuk memasuki dunia kerja.

Fase kedua antara tahun 1975-1989, fase ini adalah fase pemberlakuan SKB (surat keputusan bersama tiga menteri tahun 1975). Madrasah pada periode ini telah memasuki dunia baru, yaitu disamakannya antara ijazah sekolah dan madrasah. Sejak saat itu banyak siswa tamatan madrasah yang melanjutkan studinya ke perguruan tinggi. Fase ketiga, madrasah pasca UU system pendidikan nasional nomor 2 tahun 1989, madrasah pada periode ini didefinisikan sebagai sekolah yang berciri khas agama Islam, maka madrasah memiliki program yang sama dengan sekolah, mulai tingkat dasar sampai menengah. Ciri ke Islamannya dilihat dari mata pelajaran agamanya lebih banyak dari sekolah, demikian juga semangat beragamanya lebih menonjol dari sekolah.

Stigma negatif yang melekat pada madrasah tersebut antara lain didasarkan pada problem-problem madrasah yang terjadi selama ini adalah :

1. Problem internal kelembagaan yang berkaitan dengan manajemen dan etos kerja madrasah yang rendah, kuantitas dan kualitas guru yang kurang memadai serta sarana dan prasarana madrasah yang masih jauh dari kecukupan. Hal ini sebagaimana dikemukakan oleh Marno dan Triyo (2008) bahwa kemampuan manajerial dan kepemimpinan kepala madrasah dianggap kurang memadai, fasilitas kurang, pendidikan apa adanya, kualitas dan inovasi rendah serta etos kerja lemah.

2. Problem eksternal atau diluar kelembagaan yang berkaitan dengan ketidakmampuan madrasah dalam merespon tuntutan masyarakat dan kemajuan zaman. Dalam kaitan ini, Malik Fajar (1999) mengatakan bahwa masyarakat kita akhir-akhir ini telah mengalami pergeseran pandangan terhadap pendidikan, mereka menganggap pendidikan tidak sekedar pemenuhan kebutuhan pengetahuan, tetapi pendidikan dipandang sebagai bentuk inverstasi masa depan. Konsekwensinya, maka lembaga itu akan 
ditinggalkan masyarakat. Kondisi sekarang inilah yang sekarang dialami oleh madrasah.

Untuk merespon problem-problem di atas, maka menurut Imam Suprayogo (2008) madrasah harus dikelola sebagai system manajemen professional dan mampu memahami serta memenuhi tuntutan masyarakat. Dengan cara ini, maka madrasah, akan memperoleh peluang yang lebih besar untuk menjadi pilihan utama dan pertama bagi masyarakat.

Membahas mengenai kelembagaan pendidikan Islam tentu tidak mungkin lepas dari objek-objek seperti madrasah, sekolah Islam, pesantren, taman pendidikan AlQur'an, perkumpulan-perkumpulan kajian Islam, kelompok masyarakat yang secara khusus membentuk atau menciptakan suatu budaya baru yang bernuansa Islam. Agar lembaga menjadi baik dan unggul, maka harus dikelola dengan manajemen yang professional. Demikian juga halnya dengan lembaga madrasah, untuk memperkuat lembaga madrasah harus dilakukan dengan cara mengelola dengan manajemen professional pula.

Secara etimologis, manajemen dari bahasa latin, yaitu dari asal kata " manus " yang berarti tangan dan " agere " yang berarti melakukan. Dalam bahasa inggris, manajemen berasal dari kata " to manage " yang berarti mengelola.

Adapun secara terminologis definisi manajemen dikemukakan oleh para ahli dengan readksi yang berbeda-beda. Menurut G.R. Terry (2009:1) manajemen adalah suatu proses yang terdiri atas perencanaan, pengorganisasian, penggerakan, pelaksanaan dan pengawasan, dengan memanfaatkan ilmu maupun seni, agar dapat menyelesaikan tujuan yang telah ditetapkan sebelumnya. Menurut Harold Koontz dan Cyril O'Donnel (1992) manajemen berhubungan dengan pencapaian suatu tujuan yang dilakukan melalui dan dengan orang-orang lain. Dengan kata lain, manajemen adalah usaha untuk mencapai suatu tujuan tertentu melalui kegiatan orang lain.

Sementara menurut James A.F Stoner (1982:3), manajemen adalah proses perencanaan, pengorganisasian, pengarahan dan pengawasan usaha-usaha para anggota organisasi dan penggunaan sumber daya. Sumber daya organisasi lainnya agar mencapai tujuan yang telah ditetapkan. Senada dengan pendapat Stoner, Lawrence A Appley mengatakan, manajemen adalah seni pencapaian tujuan yang dilakukan melalui usaha orang lain.

Dari berbagai pendapat di atas, dapat disimpulkan bahwa manajemen adalah suatu proses yang khas terdiri atas tindakantindakan berupa perencanaan, pengorganisasian, penggerakan, dan pengendalian yang dilaksanakan untuk menetukan serta mencapai sasaran-sasaran atau tujuan yang telah ditentukan melalui pemanfaatan sumber daya manusia dan sumber-sumber lainnya. Dapat juga ditegaskan, manajemen adalah proses pengkoordinasian dan pengintegrasian semua sumber daya untuk mencapai tujuan yang ditetapkan.

Selain manajemen juga diperlukan peran kepemimpinan dalam membangun suatu lembaga atau organisasi yang baik. Berbagai riset juga telah membuktikan bahwa faktor pemimpin memegang peranan penting dalam mengembangkan organisasi atau lembaga. Faktor pemimpin yang sangat penting adalah karakter dari orang yang menjadi pemimpin tersebut, sebagaimana dikemukakan oleh Covey dalam Muhaimin (2015:29) bahwa 90 persen dari semua kegagalan kepemimpinan adalah kegagalan pada karakter.

Secara definisi, kemimpinan memiliki berbagai perbedaan pada berbagai hal, namun demikian yang pasti ada dari 
definisi kepemimpinan adalah adanya suatu proses dalam kepemimpinan untuk memberikan pengaruh secara social kepada orang lain, sehingga orang lain tersebut menjalankan suatu proses sebagaimana diinginkan oleh pemimpin. Berbagai perbedaan definisi tersebut tentu saja karena dibangun oleh teori yang berbeda.

Mintzberg mengemukakan bahwa kepemimpinan adalah kemampuan untuk melangkah keluar dari budaya yang ada dan memulai proses perubahan evolusioner yang lebih adaptif. Para pengembang teori transformasional melihat bahwa pemimpin memiliki tugas menyelelaraskan, menciptakan, dan memberdayakan. Para pemimpin melakukan transformasi terhadap organisasi atau lembaga dengan menyelaraskan sumber daya manusia dan sumber daya yang lain, menciptakan sebuah budaya organisasi yang menyuburkan ekspresi gagasan secara bebas, dengan memberdayakan orang-orang untuk memberikan kontribusi terhadap organisasi atau lembaga.

Dari teori tersebut di atas terlihat bahwa pemimpin harus mampu memberikan pengaruh kepada orang lain. Seorang pemimpin memiliki sifat-sifat yang unggul yang mampu membawa orang lain pada suatu kondisi tertentu. Dan seorang pemimpin harus mampu menstranformasi keluar dari budaya yang ada, menuju sutau budaya

baru yang lebih baik, untuk melakukan transformasi budaya, maka pemimpin harus dianut.

Adapun pemahaman terkait dengan fokus masalah penelitian ini adalah bahwa penguatan mutu madrasah swasta dimaksudkan untuk memperbaiki kualitas kehidupan madrasah swasta yang berbasis pada kekuatan atau daya yang mereka miliki sendiri, melalui optimalisasi daya dan peningkatan posisi tawar yang mereka miliki. Dari pemahaman tersebut mengandung makna bahwa penguatan mutu madrasah swasta harus menempatkan kekuatan sendiri sebagai modal utama, sementara pihak luar seperti pemerintah dan lembaga lain yang berkepentingan dipandang sebagai modal pelengkap. Dan tujuan dari penelitian ini dalah untuk mengungkap atau mengetahui penguatan mutu madrasah swasta menuju madrasah unggul.

\section{B. METODE PENELITIAN}

Metode penelitian yang digunakan adalah metode kualitatif. Metode kualitatif merupakan metode penelitian yang digunakan untuk meneliti para kondisi objek yang alamiah (natural setting). Sugiono (2014:1). Adapun karakteristik penelitian kualitatif menurut Daymon dan Halloway dalam Tohirin (2012:3) adalah :

Berfokus pada kata

1. Menuntut keterlibatan peneliti (partisipatif)

2. Dipengaruhi sudut pandang partisipan (orang yang menjadi sumber data)

3. Fokus peneliti yang holistik

4. Desain dan penelitiannya bersifat fleksibel

5. Lebih mengutamakan proses dari pada hasilnya

6. Menggunakan latar alami

7. Menggunakan analisis induktif baru deduktif

\section{HASIL DAN PEMBAHASAN}

Hasil analisis penelitian tentang penguatan mutu madrasah swasta menuju madrasah unggul adalah :

1. Mengoptimalkan

manajemen

\section{kelembagaan madrasah}

Kondisi eksternal kelembagaan yang sangat cepat berubah merupakan sebuah tantangan utama dari lembaga untuk dapat hidup terus. Sebagaimana makluk hidup. Lembaga juga harus pandai menyesuaikan 
diri dengan lingkungannya. Jika menginginkan untuk hidup dalam usia yang lebih panjang. Ketidakmampuan lembaga menyesuaikan diri dengan lingkungannya, akan dapat menyebabkan lembaga tersebut mengalami masalah serius bahkan dapat berakhir dengan kematian (kebangkrutan).

Dalam hal kondisi pendidikan di Indonesia, termasuk yang berkaitan dengan madrasah, perubahan tersebut dapat dilihat pada berbagai hal, mulai dari kebijakan penyelenggaraan dari pemerintah, sampai dengan perubahan sebagai hasil perkembangan ilmu pengetahuan dan teknologi. Perubahan sebagai akibat kebijakan pemerintah misalnya, perubahan dari sistem sentralisasi menjadi system disentralisasi, sehingga muncul model manajemen berbasis sekolah atau madrasah (MBS/M). Perubahan pola pengelolaan, sehingga muncul komite sekolah atau madrasah, dewan pendidikan, lembaga penjamin mutu pendidikan dan lain-lain. Perubahan yang berkaitan dengan perubahan ilmu pengetahuan dan teknologi misalnya, perubahan dalam proses pelajaran. Sehingga menghasilkan teori pembelajaran kuantum (quantum teaching/learning), pembelajaran aktif (active learning), pembelajaran konstektual (contextual teaching and learning). Perubahan dalam manajemen misalnya, manajemen mutu terpadu (total quality management) penggunaan alat analisis dan lain-lain.

\section{Pengembangan (entrepreneur)} wirausaha

Istilah kewirausahaan dan kewiraswastaan itu sesungguhnya bermuara pengertiannya pada istilah asing yakni entrepreneurship, yang artinya suatu proses penciptaan sesuatu yang baru atau inovasi guna memperoleh kesejahteraan atau kekayaan individu dan mendapatkan nilai tambah bagi masyarakat. Kesejahteraan atau nilai tambah masyarakat sebagai tujuan dari kewirausahaan itu, dilakukan melalui pengungkapan gagasan baru, penggalian sumber daya, dan merealisasikan gagasan itu menjadi suatu kenyataan yang menguntungkan.

Mencermati makna kewirausahaan di atas, maka kewirausahaan dalam pendidikan merupakan kerja keras yang terus menerus yang dilakukan pihak madrasah terutama kepala madrasah dalam menjadikan madrasahnya lebih bermutu. Konsep kewirausahaan ini meliputi usaha membaca dengan cermat peluang-peluang, melihat setiap unsur institusi madrasah adanya sesuatu yang baru atau inovatif, menggali sumber daya secara realistis dan dapat dimanfaatkan, mengendalikan resiko, mewujudkan kesejahteraan (benefit) dan mendatangkan keuntungan finansial (profits). Benefit dan profits ini terutama dilihat untuk kepentingan peserta didik, guru-guru, kepala madrasah, staf, orang tua, pemerintah, dan masyarakat sekitar atau masyarakat yang lebih luas lagi.

Hal penting yang patut dipahami para kepala madrasah dalam praktek manajemen di masyarakat adalah tuntutan untuk mengubah pola manajemen konvensional menjadi pola manajemen entrepreneurial.

Kepala madrasah hendaklah dapat mengidentifikasi pola-pola manajemen yang biasanya dilakukan. Jika memang dalam beberapa kepala madrasah itu masih menunjukkan pola manajemen konvensional, hendaknya ia dapat mengubahnya (melatih diri) menjadi polapola manajemen yang bersifat entrepreneurial.

Adapun strategi kewirausahaan merupakan langkah-langkah pokok yang perlu ditempuh kepala madrasah dalam menjadikan sebagai organisasi atau 
lembaga yang bersifat kewirausahaan (entrepreneurial organization). Strategi kewirausahaan mencakup pengembangan visi dan misi, dorongan inovasi dan perstrukturan iklim kewirausahaan.

\section{Mengoptimalkan} kepala madrasah

kepemimpinan

Pekerjaan pemimpin merupakan pekerjaan yang berkaitan dengan menentukan arah suatu lembaga, sedangkan bagaimana arah tersebut dituju merupakan pekerjaan manajerial. Karena pekerjaan kepemimpinan merupakan pekerjaan awal, maka seringkali tampak bahwa pekerjaan ini dilakukan dengan tidak memiliki pola, penuh resiko dan seringkali bagi kebanyakan orang memiliki ketidakpastian yang tinggi. Hal ini sangat berbeda dengan pekerjaan manajerial yang berkaitan dengan pola pengerjaan yang jelas, serta memiliki kepastian hasil yang jelas.

Pekerjaan pemimpin merupakan pekerjaan yang berkaitan dengan manusia. Memimpin berarti memimpin manusia, tidak ada memimpin barang atau benda, juga tidak ada memimpin hewan. Karena pekerjaan tersebut berkaitan dengan manusia, maka memimpin harus mampu memperbaiki daya berfikir manusiamanusia yang ada dalam madrasah. Untuk memperbaiki gaya berfikir manusia yang ada dalam organisasi, maka pemimpin harus mampu mengubah peta yang digunakan untuk berfikir manusia dalam madrasah tersebut. Peta berfikir tersebut bisa disebut dengan paradigm atau mindset. Jika orang-orang dalam organisasi mengerjakan pekerjaan dengan menggunakan paradigm yang salah, maka akan sangat banyak ketidak sesuaian dan bahkan mungkin kesalahan-kesalahan yang terjadi dalam organisasi tersebut. Minsdset adalah peta berfikir dan agar madrasah menjadi unggul, maka madrasah sangat tergantung pada sumber daya manusia (SDM) yang ada di dalamnya. Sedangkan agar SDM yang ada di madrasah tersebut menjadi SDM yang unggul, maka mindset orang-orang yang ada dalam madrasah tersebut harus diubah atau dikembangkan untuk dapat menjadi SDM yang unggul.

Itulah sebabnya sebuah lembaga yang memiliki pemimpin yang hebat, maka lembaga tersebut akan tumbuh dan berkembang dengan baik, walaupun secara manajerial kurang baik. Namun, jika sebuah madrasah memiliki pemimpin yang baik sekaligus pemimpin tersebut memiliki kemampuan manajerial yang handal dapat dipastikan bahwa perkembangan madrasah tersebut akan sangat cepat untuk mencapai keunggulan.

\section{KESIMPULAN}

Untuk penguatan mutu madrasah swasta menuju madrasah yang unggul, maka harus dilakukan optimalisasi manajemen kelembagaan madrasah, mewujudkan dan mengembangkan wirausaha madrasah, dan mengoptimalkan kepemimpinan kepala madrasah.

\section{E. REFERENSI}

Ahmad. Muhammad Abdul Kadir. (2008). Metodologi Pengajaran Agama Islam. Jakarta: Rineka Cipta

Alma. Buchari. (2005). Pemasaran Statejik Jasa Pendidikan. Bandung: Alfabeta

An-Nahlawi. Abdurrahman. (2004). Pendidikan Islam di Rumah Sekolah dan Masyarakat. terj. oleh Shihabuddin. Jakarta: GIP.

Budimansyah. Dasim. (2008). Peningkatan Mutu Pendidikan Melalui Penguatan Partisipasi Masyarakat. Educationist. 2 (1) 
Dean. Joan. (1993). Managing The Secondary School. London: Routledge Engkoswara. dan Komariah. Aan. (2010). Adminiatrasi Pendidikan. Bandung: Alfabeta

Gelsthorpe. Tony. dan West-Burnham. John. (2003). Educational Leadership and the Community; Strategies for School Improvement Through Community Engagement. London: Pearson

Hefner. Robert W. (2009). Making Modern Muslims ; The Politics of Islamic Education in Southeast Asia. Honolulu: University of Hawai Press

Hidayat. Ara dan Machali. Imam. (2010). Pengelolaan Pendidikan. Bandung: Educa

Hornby. Garry. (2011). Parental Involvement in Chilhood Education. New York: Springer

Hoy. Charles. at .all. (2000). Improving Quality in Education. London: Falmer Press

Hoy. Wayne K. Dan G. Miskel. Cecil. (2008). Educational Administration; Theory, Research, and Practice. McGraw-Hill

Komariah. Ara dan Triatna. Cepi (2006). Visionary Leadership; Menuju Sekolah Efektif . Jakarta: Bumi Aksara

Maslowski. (2006). A review of inventories for diagnosing school culture. Journal of Educational Administration. Vol. 44 No. 1. Emerald Group Publishing

Meirawan. Danny. (2010). Kepemimpinan dan Manajemen Pendidikan Masa Depan. Bandung: IPB Press

Muhaimin. (2004). Paradigma Pendidikan Islam. Bandung: Remaja Rosdakarya

Nurdin. Ali. (2010). Qur'anic Society; Menelusuri Konsep Masyarakat Ideal Dalam Al-Qur'an. Jakarta: Erlangga
Palmer. Joy A. (2001). Fifty Major Thinkers on Education. London and New York: Routledge

Pidarta. Made. (1997). Landasan Kependidikan. Jakarta: Rineka Cipta

Sagala. Syaiful. (2008). "Dukungan dan Partisipasi Masyarakat dalam Penyelenggaraan Pendidikan Khususnya di Sekolah". Generasi Kampus, 1 (2)

Sallis. Edward. (1993). Total Quality Management in Education. London: Kogan

Sukmadinata. Nana Syaodih. dkk. (2008). Pengendalian Mutu Pendidikan Sekolah Menengah. Bandung: Refika Aditama

Tafsir. Ahmad. (2010). Ilmu Pendidikan dalam Perspektif Islam. Bandung: Remaja Rosdakarya

Tobroni. (2012). Percepatan Peningkatan Mutu Madrasah. dalam http//researchengines.com/drtobroni507.html 